\title{
Production of Patient Specific Probes for the Detection of Minimal Residual Disease in Acute Lymphoblastic Leukemia
}

\author{
Dian Tirza $^{*}$, Marleen Bakkus ${ }^{\star *}$
}

\begin{abstract}
Abstrak
Dua puluh dua penderita ALL (acute lymphoblastic leukemia) pada anak-anak, setelah didiagnosis lalu dianalisis konfigurasi Ig (immunoglobulin) dan TcR- $\delta$ (T-cell receptor-delta) gennya dengan metode Southern blot. Pendeteksian gene rearrangements ini menunjukkan apakah junctional region konfigurasi IgH (immunoglobulin heavy chain) atau TcR-ठ akan dianalisis dengan PCR (polymerase chain reaction). Urutan nukleotida Junctional regions dari rearranged IgH (immunoglobulin heavy chain) dan TcR- $\delta$ genes ditentukan dengan direct sequencing hasil produk PCR daerah ini. Berdasarkan data sekuens ini, maka pelacak yang spesifik terhadap pasien tersebut (patient-specific oligonucleotide probes) akan didesain. Selanjutnya, sumsum tulang dan darah tepi yang diambil selama dan setelah pengobatan, akan dianalisis dengan teknik PCR menggunakan pelacak yang spesifik terhadap pasien tersebut untuk mendeteksi sel leukemik Lima pelacak yang spesifik telah didesain dan diuji spesifisitas dan sensitivitasnya.
\end{abstract}

\begin{abstract}
Twenty-two patients with childhood ALL were analyzed for the configuration of their Ig (immunoglobulin) and TcR- $\delta$ (T cell receptor delta) genes by Southern blot analysis. The detection of gene rearrangements indicated whether lgH (immunoglobulin heavy chain) or TcR- $\delta$ junctional regions should be analyzed by PCR (Polymerase chain reaction). The nucleotide sequence of junctional regions of the rearranged IgH and TcR- $\delta$ genes are determined by direct sequencing of PCR products of these regions. Based on the sequence data, patient-specific oligonucleotide probes were designed. Subsequently, bone marrow and/or peripheral blood samples taken during and after treatment, will be analyzed with the PCR technique, using patient -specific oligonucleotide probes for the detection of leukemic cells. Five patient specific probes have been designed and tested in specificity and sensitivity.
\end{abstract}

Keywords : ALL (Acute Lymphoblastic Leukemia), MRD (Minimal Residual Disease), IgH (Immunoglobulin Heavy Chain) gene, $T c R-\delta$ (T-cell receptor-delta) gene.

\section{INTRODUCTION}

Approximately $20-30 \%$ of children with ALL showed a relapses, in spite of major improvements in the treatment achieved during the last two decades. Apparently, the current treatment is not adequate to kill all the leukemic cells, although the vast majority appear to reach complete remission according to the current morphological detection technique. The detection limit of this technique is about $1-5 \%$ (1-5 leukemic cells in 100 normal cells). It is obvious that this technique only provides superficial information on the result of leukemia treatment. ${ }^{1,2,3}$
Therefore, more sensitive techniques are required for the detection of lower numbers of leukemic cells to determine whether the tumor load can be decreased during treatment.

The terminology of MRD (minimal residual disease) means that the leukemic cells are present in the peripheral blood or bone marrow at a level below the detection limit of conventional technique. ${ }^{4}$

Now by using recombinant DNA technology it is possible to recognize MRD in ALL by analyzing the rearrangements of the Ig and TcR genes, as illustrated in Figure 1 and Figure 2.

\footnotetext{
* In partial fulfillment of the requirements for the degree of Master of Science in Molecular Biology, Vrije Universiteit Brussel (V.U.B), Belgium.

* Department of Pharmacology, Faculty of Medicine University of Indonesia, Jakarta, Indonesia.

** Department of Hemato-Immunology, Clinical Research of A2-Vrije Universiteit Brussel (V.U.B), Belgium.
} 
The IgH genes are rearranged in $98 \%$ of cases of B-cell ALL, and 45-50\% rearranged Ig light chain (IgL) genes, ${ }^{5,6,7,8}$ The rearrangement of IgH genes are detectable with a JH probe (see Appendix 1) after digestion with the restriction enzymes of $\mathrm{Bgl}$ II, $\mathrm{Bam}$ HI, and Hind III. The rearrangements of TcR- $\delta$ genes occur in more than $90 \%$ of T-ALL, $65 \%-70 \%$ of precursor B-ALL which is detectable by $\mathbf{J} \delta 1$ probe (see Appendix 1).

The general aim of the project was detection of MRD in childhood of ALL, by studying the junctional region of IgH and TcR- $\delta$ gene rearrangements by the PCR. Therefore, first of all the configuration of their IgH and TcR- $\delta$ genes were analysed by use of Southern blot. Subsequently, the sequence of junctional regions of rearranged $\mathrm{IgH}$ and $\mathrm{TcR}-\delta$ genes will be determined by direct sequencing of PCR products of these regions. From the sequence data can produce patient specific probes. Finally, this information will be used to detect leukemic cells after treatment and evaluate whether the treatment of ALL can be improved.

\section{MATERIALS AND METHODS}

\section{Cases}

The biological specimens that was studied consisted of peripheral blood (PB) and bone marrow (BM) samples obtained from 22 children with immunophenotypic common ALL, B-cell ALL and T- cell ALL. They aged between 2 and 9 years old. These children were treated with different multidrug regimens.

\section{Isolation of lymphocytes}

DNA was extracted from fresh cells or frozen cells which were isolated from $\mathrm{PB}$ or $\mathrm{BM}$ according to the method described by Maniatis et al. ${ }^{9}$

\section{Southern Blot}

Ten ug of this DNA was digested with the restriction enzymes (Pharmacia, Uppsala, Sweden), electrophoresed in $0.8 \%$ agarose gel, and transferred onto a Hybond $\mathrm{N}^{+}$membrane (Amersham, Tokyo, Japan). Then hybridization of Southern blots consisted of prehybridization step, probe labelling, hybridization with ${ }^{32} \mathrm{P}$-labelled probe and post-hybridization washes. ${ }^{9}$ The availability of detailed information about the sizes of germline and rearrangement restriction fragments in $\mathrm{Kb}$ is a prerequisite for an accurate result (see Appendix 2).

\section{Polymerase chain reaction}

PCR was carried out as described by Saiki et al ${ }^{10}$ using the denaturation step at $94^{\circ} \mathrm{C}$ for 30 seconds, an annealing step at $55^{\circ} \mathrm{C}$ for 30 seconds, and an extension at $72^{\circ} \mathrm{C}$ for 1 minute 20 seconds. This was done for 40 cycles (for $\mathrm{IgH}$ ). For V82-D 83 rearrangements, the samples were subjected to the following cycles : the denaturation step at $95^{\circ} \mathrm{C}$ for 5 minutes, the annealing step at $66^{\circ} \mathrm{C}$ for 2 minutes, and the extension at $72^{\circ} \mathrm{C}$ for 40 seconds. This was done for 40 cycles in Thermocycler (Bio-Med, B.Braun, F.R.G). As negative control sample, a reaction was performed with $\mathrm{H}_{2} \mathrm{O}$ instead of template DNA. Oligomers used in the PCR is described in Appendix 3.

\section{Direct sequencing}

Direct sequencing step consisted of purification of amplified DNA (Promega Corporation, USA), preparation of Dynabeads M-280 streptavidin (Dynal $^{(\mathrm{R})}$, Norway Co As), separation of DNA strands, annealing mixture, labeling reaction and termination reaction.

The biotinylated primer was used for direct sequencing.

\section{Dot Blot Hybridization}

The PCR product was serially diluted $10^{\circ}-10^{4}$ times starting from $5 \mu \mathrm{l}$ (1:10 of the total volume of PCR product), then denaturated by adding $4 \mu \mathrm{l}$ of $5 \mathrm{~N} \mathrm{NaOH}$ $+1 \mu$ of $0.5 \mathrm{M}$ EDTA (pH 8.2) and incubated at $95^{\circ} \mathrm{C}$ for 10 minutes. The samples were then chilled on ice and $50 \mu \mathrm{l}$ of $2 \mathrm{~N} \mathrm{NH}_{4}$ acetate $\mathrm{pH} 7.0$ was added. Subsequently, the samples were immobilized on a piece of Zeta Probe Membrane (Biorad membranes No: 162-0153), using the Bio-rad dot blot apparatus (Biorad). After application of the DNA on the membrane, the wells were rinsed with $500 \mu$ l of $0.4 \mathrm{~N}$ $\mathrm{NaOH}$. After removing the membrane, it was washed in 2X SSC for 5 minutes ( 3 times). Subsequently, the membrane was air dried and stored or hybridized immediately

\section{RESULTS}

Configuration of the TcR- $\delta$ and $\operatorname{IgH}$ genes by Southern blot

The rearrangements of the $\mathrm{IgH}$ gene were detected with a JH specific probe. Whereas, the rearrangements of the TcR- $\delta$ gene were detected with a J $\delta$ probe. An example of such a Southern blot experiment is shown in Figure 3. Four ALL samples were hybridized with 


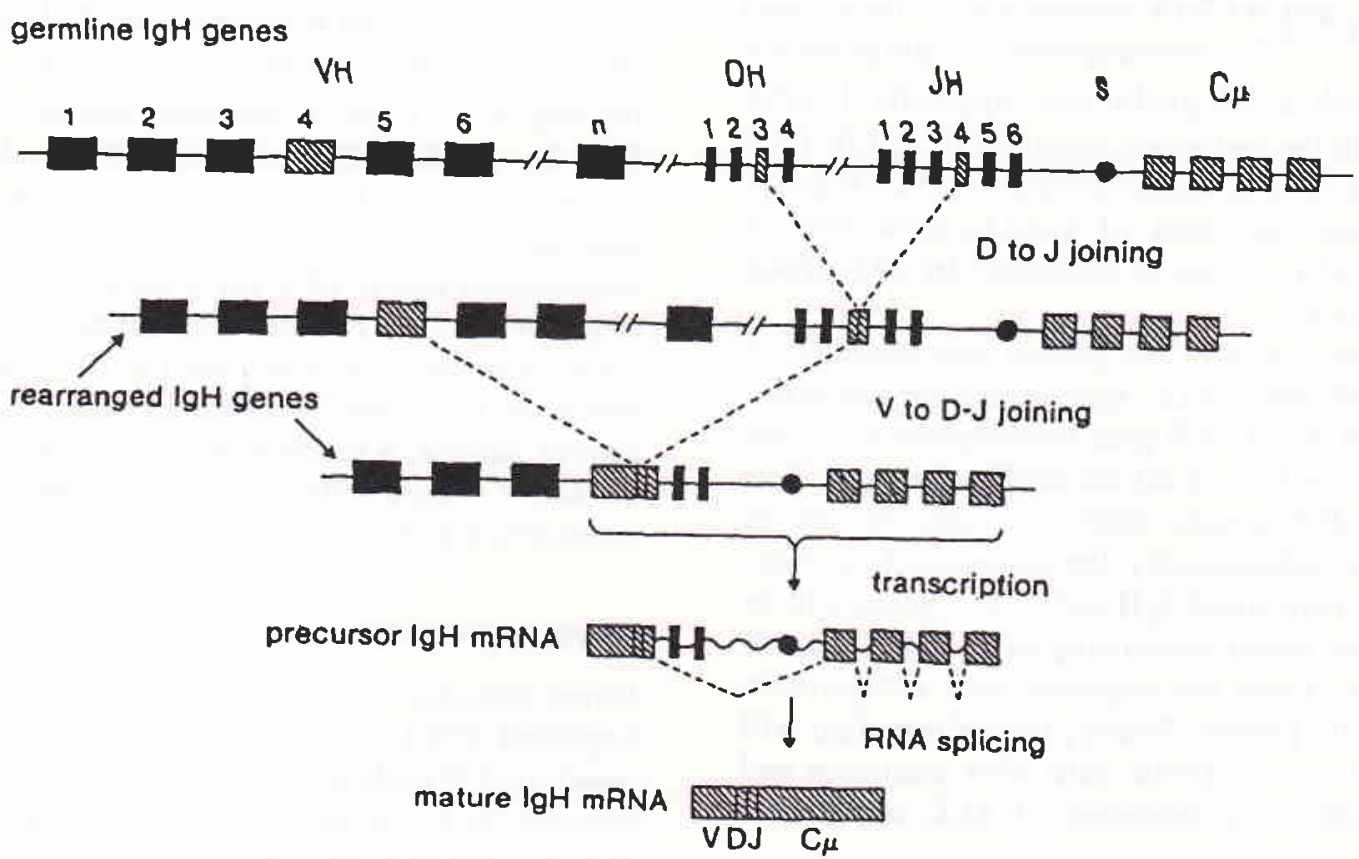

Figure 1. Rearrangement of immunoglobulin heavy chain gene. First $D$ to J joining occurs, followed by V to D-J joining. The rearranged genes can be transcribed into a precursor IgH $m R N A$; which becomes a mature Ig $M R N A$ after splicing. ${ }^{1 I .12}$

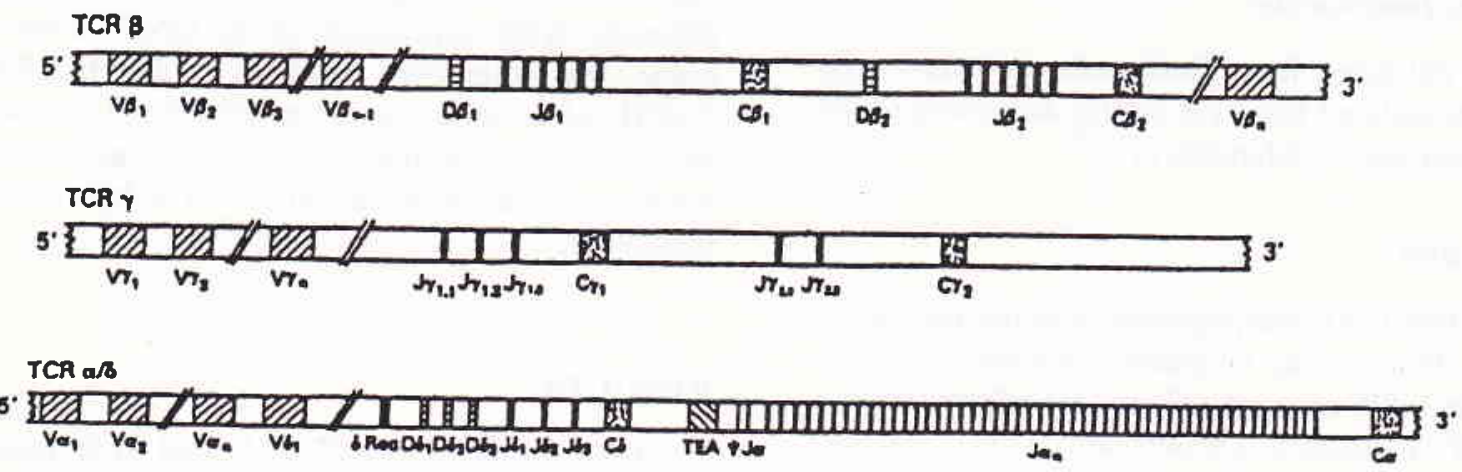

Figure 2. The structure of the germline TcR genes in human. ${ }^{12}$ 
the J81 probe. BM and / or PB DNA of 4 ALL samples was cut with $E c o$ RI (Figure $3 \mathrm{~A}$ ) or $B g L I I$ (Figure $3 B$ ). In $B g L$ II and Eco RI, these samples showed rearrangements of the TcR- $\delta$ gene (V $\delta 2-D \delta 3$ rearrangement,

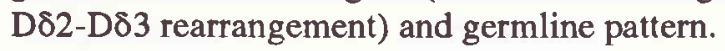

Twenty two ALL patients were analyzed by Southern blotting. The results are shown in Table 1. Analysis of all these data indicated that rearrangement of TcR- $\delta$ region (see Table 2) and rearrangement of $\mathrm{IgH}$ gene region have occurred (see Table 3 ).

A

B

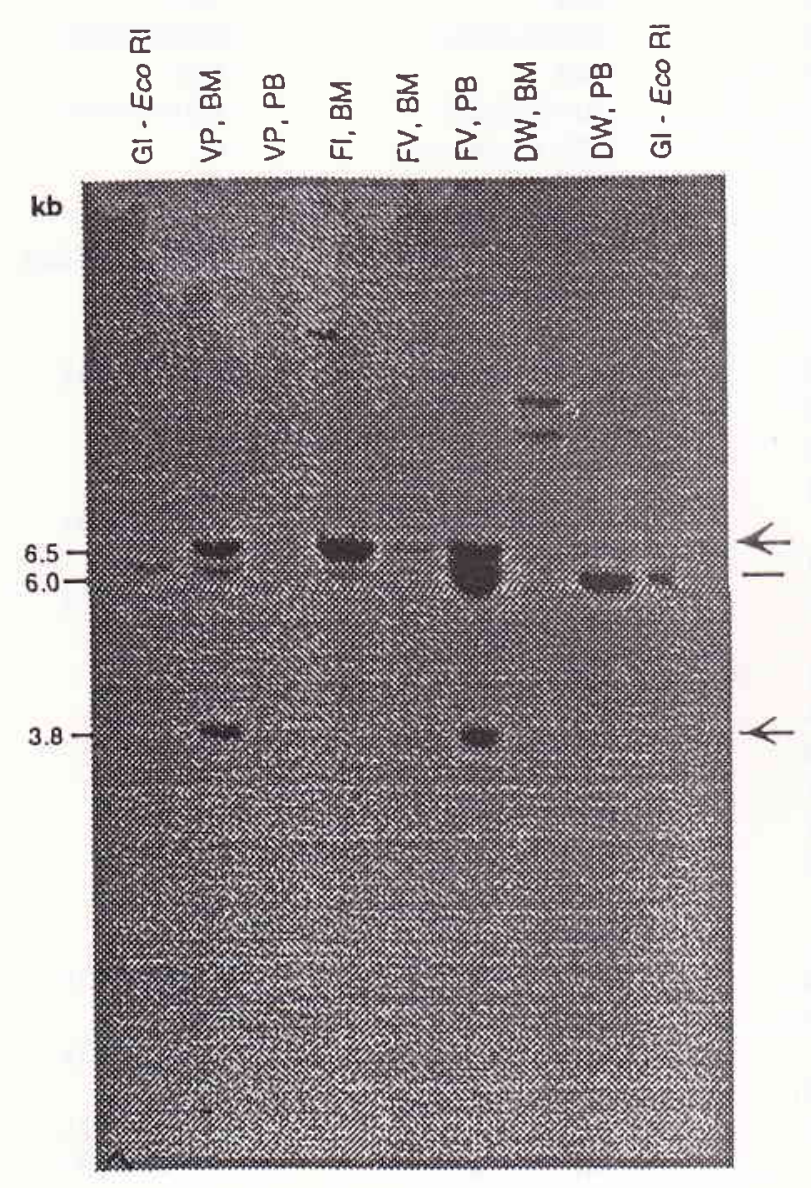

J $\delta 1$ - probe

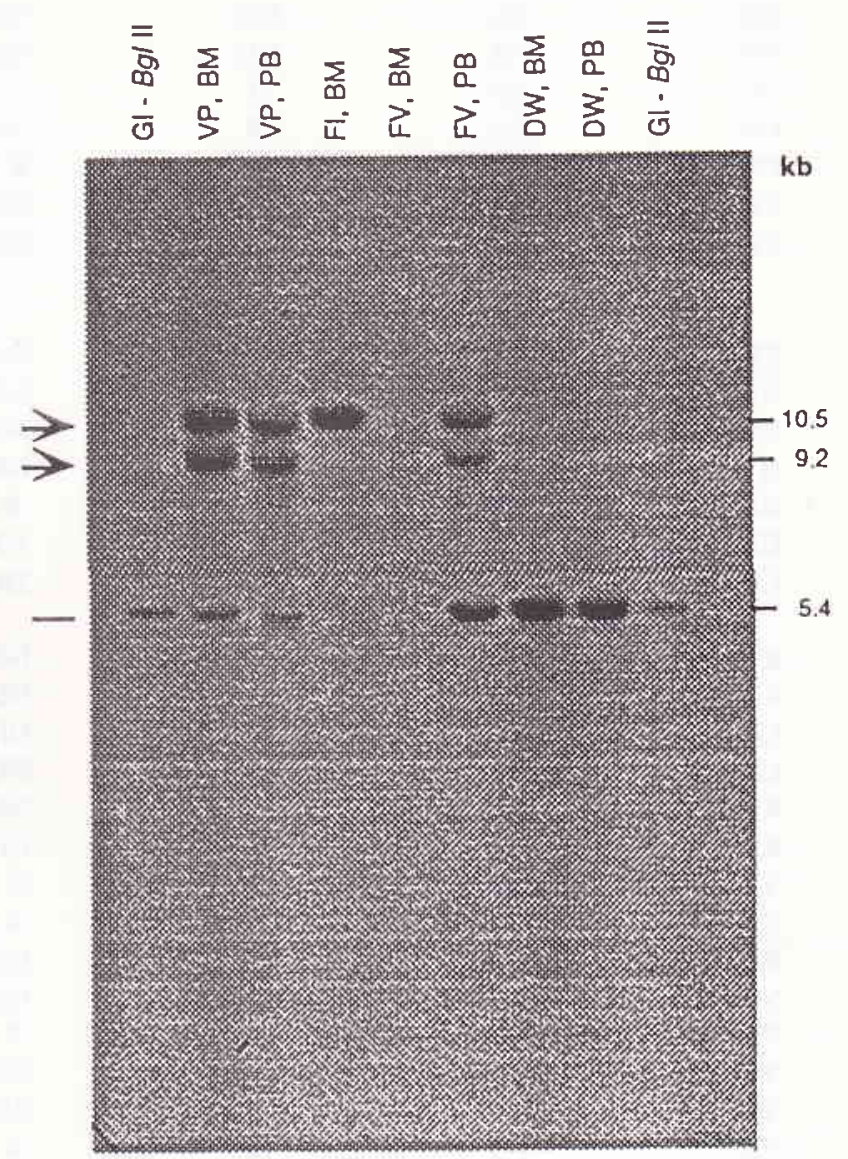

$J \delta 1$ - probe

Figure 3. TcR-8 gene configuration in 4 ALL patients. DNA samples from BM/or PB samples were digested with Eco RI (A) and Bgl II $(B)$. The membrane was hybridized with ${ }^{32} P$ labeled $J \delta 1$ probe. Arrows indicated $T c R-\delta$ rearrangements. Solid bar indicated germline. * : unknown TCR-ठ rearrangements. 
Table 1. Configuration of IgH and TcR- $\delta$ genes rearrangements in childhood ALL by Southem blot analysis.

\begin{tabular}{|c|c|c|c|c|c|}
\hline \multirow{2}{*}{ Name of patients } & \multirow{2}{*}{ Source* } & \multicolumn{2}{|c|}{$\mathrm{IgH}$} & \multicolumn{2}{|c|}{$T c R-\delta$} \\
\hline & & Eco RI & $B g / \mathrm{II}$ & Eco RI & $B g / I$ \\
\hline $\mathrm{BF}$ & BM & $\mathbf{R}$ & $\mathbf{R}$ & 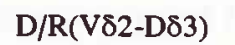 & D/R(V82-D83) \\
\hline BN & BM & ** & ** & R(V82-D83) & $R(V 82-D 83)$ \\
\hline BN & PB & NR & G & G & G \\
\hline $\mathrm{BC}$ & BM & ** & ** & R(V82-D83) & R(V82-D83) \\
\hline $\mathrm{BC}$ & PB & ** & $\star *$ & R(V82-D83) & R(V82-D83) \\
\hline $\mathrm{CW}$ & $\mathrm{BM}$ & NR & NR & ND & ND \\
\hline $\mathrm{CW}$ & PB & NR & NR & G & G \\
\hline $\mathrm{CK}$ & $\mathrm{BM}$ & ND & ND & ND & ND \\
\hline CK & PB & ND & ND & ND & ND \\
\hline $\mathrm{DB}$ & BM & ND & ND & $\mathrm{R}(\mathrm{D} \delta 2-\mathrm{D} \delta 3)$ & $\mathrm{R}$ (D82-D83) \\
\hline DB & PB & ND & ND & ND & ND \\
\hline DC & BM & G & G & $R(V 82-D \delta 3)$ & $\mathrm{R}$ (D82-D83) \\
\hline DW & $\mathrm{BM}$ & $2 \mathrm{R}$ & $2 \mathrm{R}$ & $2 R^{\star}$ (unknown) & G \\
\hline DW & PB & $\mathbf{R}$ & $\mathbf{R}$ & $\mathrm{G}$ & G \\
\hline FV & BM & $2 \mathrm{R}$ & $2 \mathrm{R}$ & R(V82-D83) & NR \\
\hline FV & $\mathrm{PB}$ & $2 \mathrm{R}$ & $2 \mathrm{R}$ & $\begin{array}{l}\text { G/2R (V82-D83, } \\
\text { D82-D } 83)\end{array}$ & $\begin{array}{l}\text { G/2R (V82-D } 83 \\
\text { D82-D83) }\end{array}$ \\
\hline FI & BM & $\mathbf{R}$ & $D / R$ & G/R(Vס2-D83) & $\mathrm{R}$ (V82-D83) \\
\hline GI & $\mathrm{BM}$ & ND & ND & ND & ND \\
\hline GL & PB & ND & ND & ND & ND \\
\hline HT & PB & NR & NR & NR & NR \\
\hline $\mathrm{HB}$ & $\mathrm{BM}$ & $\mathbf{R}$ & $\mathrm{R}$ & R(V82-D83) & R(V82-D83) \\
\hline HB & PB & ND & ND & ND & ND \\
\hline JA & $\mathrm{BM}$ & $2 \mathrm{R}$ & $2 \mathrm{R}$ & $\begin{array}{l}\text { 2R(V82-D83, } \\
\text { D } 82-D \delta 3)\end{array}$ & 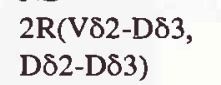 \\
\hline KY & BM & ND & ND & ND & ND \\
\hline KY & $\mathrm{PB}$ & ND & ND & ND & ND \\
\hline LN & $\mathrm{BM}$ & G & $G / R$ & G & G \\
\hline LN & PB & ND & ND & G & G \\
\hline RM & $\mathrm{BM}$ & NR & NR & G & G \\
\hline $\mathrm{RM}$ & PB & $\mathrm{R}$ & $G / R$ & G & G \\
\hline VB & BM & ND & $\mathrm{R}$ & ND & ND \\
\hline VB & PB & $\mathbf{R}$ & $\mathrm{R}$ & ND & ND \\
\hline $\mathrm{VC}$ & $\mathrm{BM}$ & NR & $\mathrm{G} / \mathrm{R}$ & $R(V \delta 2-D \delta 3)$ & $\mathrm{R}(\mathrm{V} \delta 2-\mathrm{D} \delta 3)$ \\
\hline VC & $\mathrm{PB}$ & G & $\mathrm{G} / \mathrm{R}$ & NR & $\mathrm{NR}$ \\
\hline VU & $\mathrm{BM}$ & $\mathbf{R}$ & $\mathrm{R}$ & $\mathrm{R}(\mathrm{V} \delta 2-\mathrm{D} \delta 3)$ & R(V82-D83) \\
\hline VU & PB & ND & ND & ND & ND \\
\hline vs & BM & $2 \mathrm{R}$ & $2 \mathrm{R}$ & $\mathrm{R}(\mathrm{V} \delta 2-\mathrm{D} \delta 3)$ & R(V82-D83) \\
\hline vs & PB & $\mathbf{R}$ & $\mathbf{R}$ & $\mathrm{R}(\mathrm{V} 82-\mathrm{D} 83)$ & R(V82-D83) \\
\hline VP & $\mathrm{BM}$ & $\mathrm{D} / \mathrm{R}$ & $\mathbf{R}$ & $\begin{array}{l}\text { G/2R(V }(\mathrm{V} 2-\mathrm{D} \delta 3, \\
\mathrm{D} \delta 2-\mathrm{D} \delta 3)\end{array}$ & R(V82-D83) \\
\hline VP & PB & $\mathbf{R}$ & $\mathbf{R}$ & NR & $\begin{array}{l}\text { G/2R(V82-D } 83 \\
\text { D } 82-D \delta 3)\end{array}$ \\
\hline
\end{tabular}

Abbreviation:

NR : no result due to technical problem.

$\mathrm{R}$ : gene segment in rearrangement configuration of $\mathrm{J} \delta 1$.

ND : not determined because not enough sample.

$\mathrm{G}$ : gene segmen in germline configuration of $\mathrm{J} \delta 1$.

D : deletion of the involved gene (segment).

* Source samples from BM (bone marrow) or PB (peripheral blood).

${ }^{\star *}$ Not yet done. 
Table 2. TcR- $\delta$ gene rearrangements in childhood ALL,

\begin{tabular}{|c|c|c|}
\hline $\mathrm{T}$ cell receptor delta & Eco RI & $B g / I I$ \\
\hline $\begin{array}{l}\frac{\text { Rearrangements of }}{T C R-\delta} \\
\text { TC }\end{array}$ & $14 / 22(63.63 \%)^{*}$ & $14 / 22(63.63 \%)$ \\
\hline One allele reartanged & $10 / 22$ & $10 / 22$ \\
\hline Both alleles rearranged & $3 / 22$ & $3 / 22$ \\
\hline $\begin{array}{l}\text { One allele deleted / } \\
\text { one rearranged }\end{array}$ & $1 / 22$ & $1 / 22$ \\
\hline
\end{tabular}

Table 3. Immunoglobin gene rearrangements in childhood ALL.

\begin{tabular}{lll}
\hline $\begin{array}{l}\text { Immunoglobulin Heavy } \\
\text { chain }\end{array}$ & $E c o$ RI & $B g l$ II \\
\hline Rearrangements of & \multicolumn{1}{c}{$14 / 22(63.63 \%)^{\star}$} & $15 / 22(68.18 \%)^{*}$ \\
$\quad$ IgH genes & $10 / 22$ \\
$\begin{array}{l}\text { One allele rearranged } \\
\text { Both alleles reartanged }\end{array}$ & $9 / 22$ & $4 / 22$ \\
$\begin{array}{l}\text { One allele deleted / } \\
\text { one rearranged }\end{array}$ & $1 / 22$ & $1 / 22$ \\
\hline
\end{tabular}

* Number of cases demonstrating rearrangements / number of cases studied

** Calculation data were obtained from table 1 .

The detection of IgH and TcR- $\delta$ rearrangements in childhood ALL by PCR technique

Most of the ALL patients had a V82-D 83 rearrangement as judged by Southern blot analysis. Therefore,

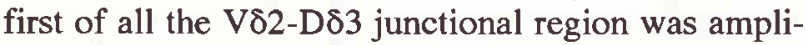
fied. The amplification products were separated in a
$1.5 \%$ agarose gel (Figure 4). The sizes of these junctional region were $400 \mathrm{bp}$.

The amplification of the $\mathrm{IgH}$ junctional region was performed by PCR using the primers FR3-5' and LJH- $3^{\circ}$. The sizes of the junctional regions were between 180-200 bp.

Fourteen cases out of the $22 \mathrm{ALL}$ patients (63.64\%) indicated amplification of V82-D83 rearrangements by PCR technique. Eight cases did not show

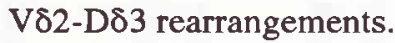

Seventeen cases out of the 22 ALL patients $(77.27 \%)$ gave amplification products when the IgH junctional regions were amplified. In 4 cases no band was obtained. One case was not yet analyzed.

The nucleotide sequences of junctional regions of rearranged TcR- $\delta$ genes.

The 14 cases of ALL with a V82-D83 rearrangement were chosen for direct sequencing. The biotinylated primer was used for direct sequencing after gel purification. The PCR products were sequenced. The sequence data were compared to published sequences confirming that the PCR products derived from V82D $\delta 3$ genes rearrangements as shown in table 4 . Sequences which are identical to $V \delta, D \delta$ and $J \delta 1$ germline sequences were identified. Other nucleotides in this region were judged a $\mathrm{N}$ region. In 7 of the 14 patients unique sequences are obtained. In 5 cases no monoclonal sequence was obtained. Two cases showed unreadable sequences. The sequences of patients KY and VP showed a deletion of D 83 gene.

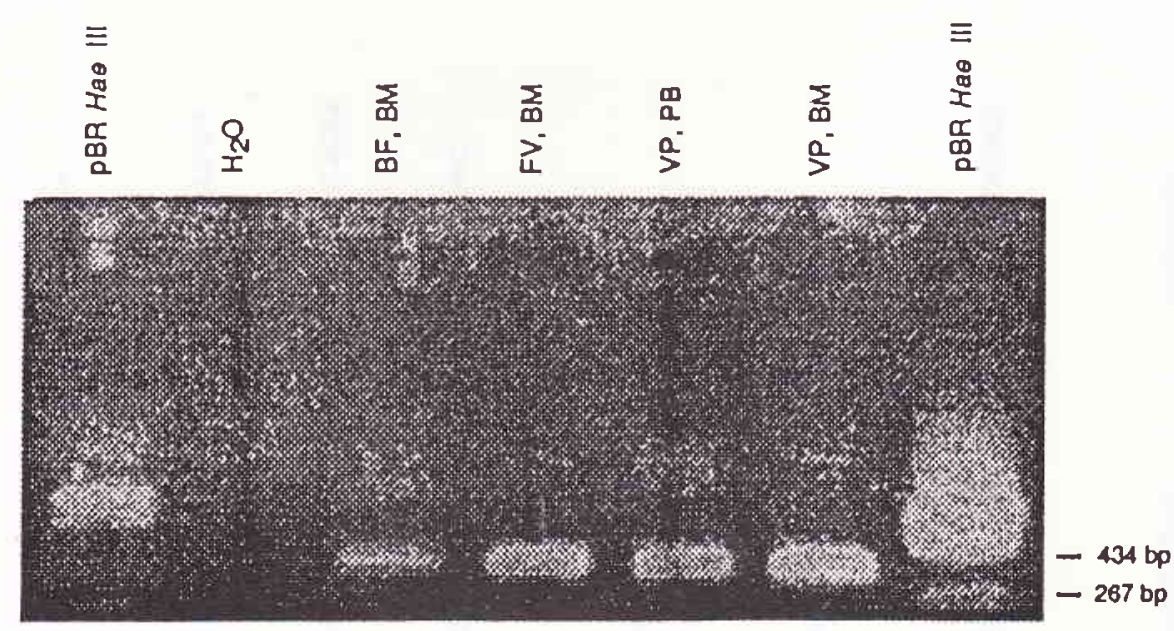

Figure 4. PCR analysis of the $V 82-D 83$ gene rearrangements in 3 ALL patients (lane 3-6). The control is $\mathrm{H}_{2} \mathrm{O}$ (Lane 2). As a marker is used $p B R$ Hae III (lane 1 and 7). 


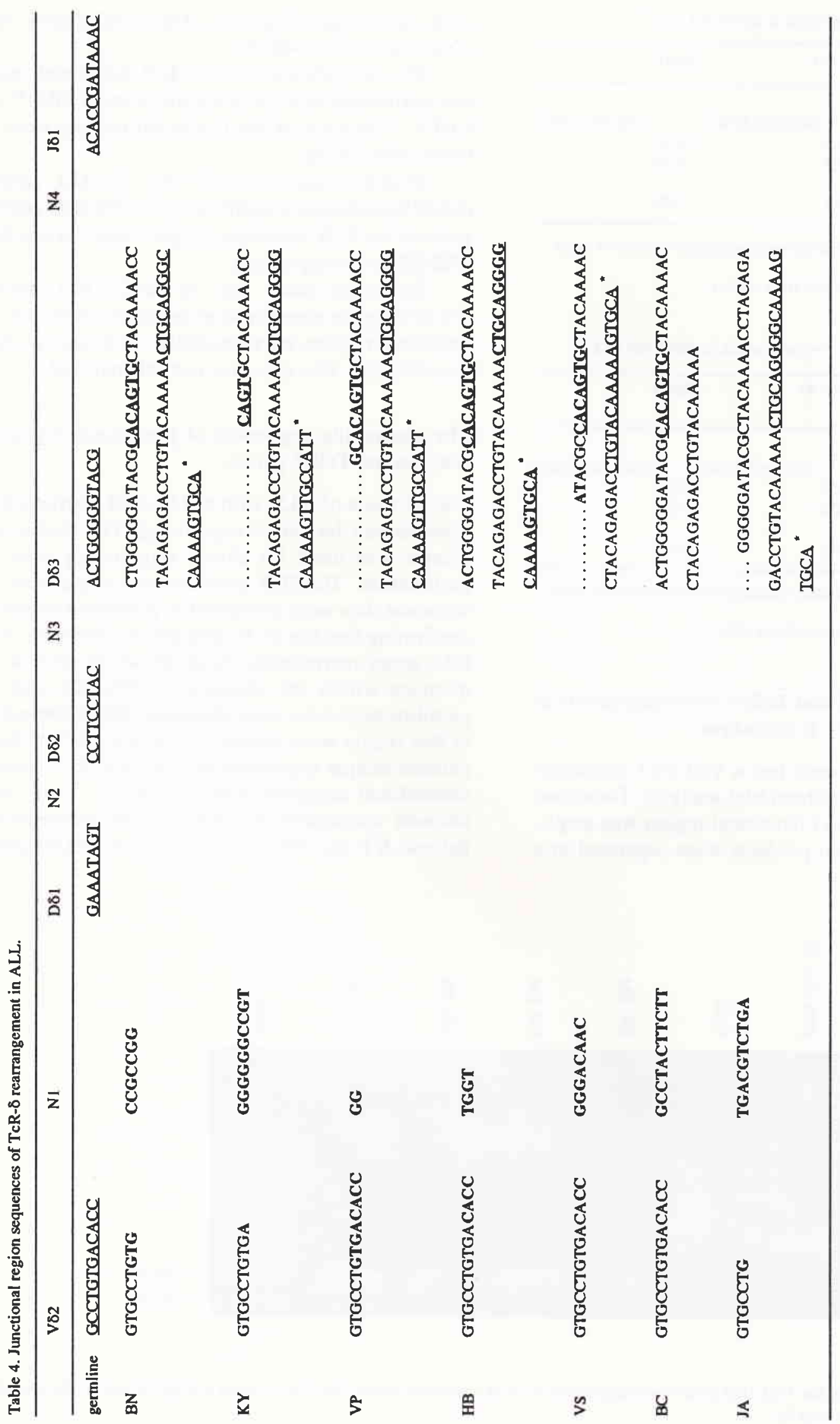

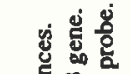

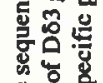

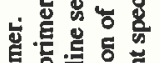

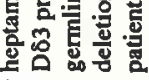
긍

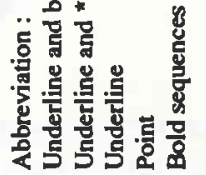




\section{Dot blot hybridization}

Five patient specific probes were used to hybridize the DNA samples, except 2 patient specific probes (VP and JA). To test the specificity of patient specific oligo's, the oligo's were end labeled with gamma- ${ }^{32} \mathrm{P}$ dCTP's and used in a dot blot hybridization experiment.
The oligo's only hybridized to the DNA samples from which they derived (Figure 5). The detection sensitivity was variable. Probes $\mathrm{HB}, \mathrm{VB}$ and $\mathrm{BC}$ only hybridized weakly probably due to the length of the oligo and consequently the low hybridization temperature $\left(32^{\circ} \mathrm{C}\right)$. Probes $\mathrm{KY}$ and $\mathrm{BN}$ gave a stronger signal, both these probes had a Tm (temperature melting) of $42^{\circ} \mathrm{C}$.
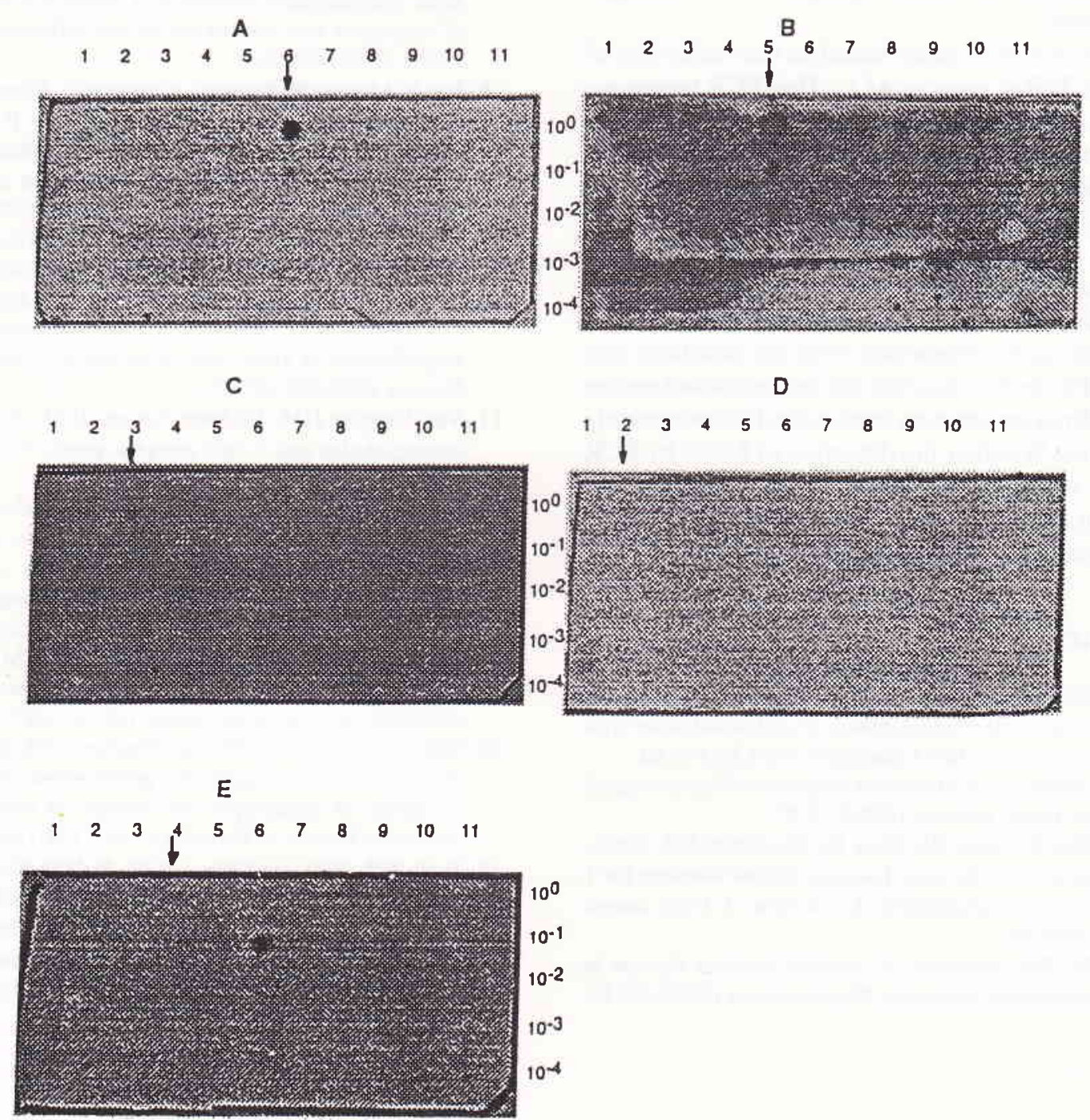

Figure 5. Each set of ALL DNA samples war amplifred by PCR (V82- D83), blawed and hybridized with leukentia speciffc oligonucleotide probe. Arrow indicates the detection of leukemic cells.

Lane 1 : normal control DNA.

Lane 2 : patient VB.

Lane 3 : patient $\mathrm{HB}$.

Lane 4 : patient BC.

Lane 5 : patient BN.

Lane 6 : patient $\mathrm{KY}$.

Lane 7 : patient VS.

Lane 8 : patient $\mathrm{V} 4$

Lane $9:$ patient VP

Lane 10 : patient DB

Lane 11 : patient GL
A : the membrane was hybridized to probe $\mathrm{KY}$.

$\mathrm{B}$ : the membrane was hybridized to probe $\mathrm{BN}$.

$\mathrm{C}$ : the membrane was hybridized to probe $\mathrm{HB}$.

$\mathrm{D}$ : the membrane was hybridized to probe VB.

$\mathrm{E}$ : the membrane was hybridized to probe $\mathrm{BC}$.

The samples were diluted starting from $5 \mu 1$ of amplification DNA in ten fold serial dilution. 


\section{DISCUSSION}

Most of the ALL patients have TcR V $\delta 2-D \delta 3$ rearrangements and $\mathrm{IgH}$ rearrangement as detected by Southern blot. Therefore, in most cases it is not necessary to perform Southern blot analysis, but only perform the PCR with the V82-5'/D83-3' primers and the FR3/LJH primers. Only in the case of negativity Southern blot can be useful to judge the TcR and $\operatorname{IgH}$ rearrangement.

We set up a PCR assay based on the variability of the IgH and TcR- $\delta$ gene in ALL. This PCR technique allows the detection of MRD in ALL. By PCR, the junctional region of TcR- $\delta$ rearrangement could be amplified in 14 cases out of 22 (63.64\%). Seventeen cases out of $22(77.27 \%)$ gave amplification product of the $\mathrm{IgH}$ rearrangement. One of the advantages of PCR are that the technique requires less DNA than the Southern blot technique. It is more sensitive and less time consuming in comparison with the Southern blot technique. The probes specific for the junctional region of the TcR- $\delta$ region are now used in the follow up study these patients. Whether the detection of MRD by PCR technology will lead to decrease of the morbidity and mortality in ALL can only be answered after multicentre evaluation of the technique.

\section{REFERENCES}

1. Katz F, Ball L, Gibson B, Chessels J. The use of DNA probes to monitor minimal residual disease in childhood acute lymphoblastic leukemia. Brit J Haematol 1989;73:173-80.

2. Fey MF, Wainscoat J. Molecular diagnosis of hematological neoplasms. Blood reviews 1988;2:78-87.

3. Jonsson OG, Kitchens RL, Baer RJ, Buchanan GR, Smith. Rearrangements of the tal-1 Locus as Clonal Markers for $T$ Cell Acute Lymphoblastic Leukemia. J Clin Invest 1991;87:2029-35.

4. Potter MN. The detection of minimal residual disease in acute lymphoblastic leukemia. Blood reviews 1992;6:68-82.
5. Toyonaga B, Yoshikai Y, Vadasz V, Chin B, Mak TW. Organization and sequences of the diversity, joining, and constant region genes of the human T-cell receptor Beta chain. Proc Natl Acad Sci USA 1985;82:8624-8.

6. Korsmeyer SJ. Antigen receptor genes as molcular markers of lymphoid neoplasms. J Clin Invest 1987;79:1291-5.

7. Nadler LM, Korsmeyer SJ, Anderson KC, Boyd AW, Slaughenhoupt B, Park E, Jensen J, Corral F, Mayer RJ, Sallan SE, Ritz J, Schlossmann SF. B cell origin of non T-cell acute lymphoblastic leukemia. A model for discrete stages of neoplastic and normal pre-B cell differentiation. J Clin Invest 1984;74:332-40.

8. Foa R, Migone N, Basso G, Cattoretti G, Pizzolo G, Lauria, F, Casorati G, Giubellino MC, Capuzzo F, Rajnoldi C, Lusso, P, Carbonara AO, Gavosto F. Molecular and immnological evidence of B-cell commitment in "Nul" acute lymphoblastic leukemia. Int. J Cancer 1986;38:317-23.

9. Maniatis T, Fritsch EF, Sambrook J. In: Molecular Cloning A Laboratory Manual. Cold Spring Harbor, New York, 1982.

10. Saiki RK, Gelfand DH, Stoffel S, Scharf SJ, Higuchi R, Horn GT, Mullis KT, Erlich HA. Primer-directed enzymatic amplification of DNA with termostable DNA polymerase. Science 1988;239:487-91.

11. Van Dongen JJM, Wolvers-Tettero ILM. Analysis of immunoglobulin and $\mathrm{T}$ cell receptor genes. Clinica Chimica Acta 1991;198:1-92.

12. Potter MN. The detection of minimal residual disease in acute lymphoblastic leukemia. Blood reviews 1992;6:68-82.

13. Felix CA, Poplack DG. Characterization of acute lymphoblastic leukemia of childhood by immunoglobulin and T cell receptor gene patterns. Leukemia 1991;5:1015-25.

14. Quetermous T, Strauss WM, Van Dongen JJM, Seidman JG. Human T-cell gamma chain joining regions and T-cell development. J of Immunology 1987;8:2687-90.

15. Jong D, Voetdijk BMH, Van Ommen GJB, Kluin PM. Alterations in immunoglobulin genes reveal the origin and evolution of monotypic and bitypic B cell lymphomas. American Journal of Pathology 1987;134:1233-42.

16. Breit TM, Wolvers-Tettero ILM, Hahlen K, Van Wering, ER, Van Dongen JJM. Extensive junctional diversity of Gamma-delta $\mathbf{T}$ - cell receptors expressed by T-cell acute lymphoblastic leukemias : Implications for the detection of minimal residual disease. Leukemia 1991;15:1076-86. 
Appendix 1. The probes required for southem blot analysis of TcR- $\delta$ gene rearrangements and IgH rearrangement

\begin{tabular}{|c|c|c|}
\hline J $\delta 1$ probe & $\begin{array}{l}\text { Clone : } \\
\text { Vector : } \\
\text { Resistance : } \\
\text { Insert (total) : } \\
\text { Bacteria : }\end{array}$ & $\begin{array}{l}\text { : pJ } \delta S 16 \\
\text { : pUC } \\
: \text { Ampicillin } \\
\text { : Sac I- Sac I 1.5 kb } \\
\text { : DH5aF }(11,14)\end{array}$ \\
\hline JH probe & $\begin{array}{l}\text { Clone } \\
\text { Vector } \\
\text { Resistance } \\
\text { Insert (total) } \\
\text { Insert (probe) } \\
\text { Bacteria }\end{array}$ & $\begin{array}{l}\text { : Pvu ll fragment of the JH gene segment } \\
\text { : in pBR } 322 \\
\text { : Ampicillin } \\
\text { : Bam HI-Hind III } 6 \mathrm{~kb} \\
\text { : Sau 3A I } \sim 2.0 \mathrm{~kb} \\
: \text { DH } 1 \text { (15) }\end{array}$ \\
\hline
\end{tabular}

Apeendix 2. Approximate sizes of germline and rearrangement restriction fragments in $\mathrm{kb}$ (exon content of restriction fragment TcR- $\delta$ gene)

\begin{tabular}{|c|c|c|c|c|c|}
\hline & Eco RI & $B g l$ II & Hind III & Bam HI & $K p n$ I \\
\hline germline J $\delta 1$ & 6.0 & 5.4 & 6.0 & 17.5 & 17.5 \\
\hline V $\delta_{1}-J \delta_{1}$ & 3.3 & 5.6 & 11.0 & $>30$ & 9.4 \\
\hline $\mathrm{V} \delta_{2}-\mathrm{J} \delta_{1}$ & 5.5 & 10.2 & 6.1 & 20 & 8.4 \\
\hline $\mathrm{V} \delta_{2}-\mathrm{D} \delta_{3}$ & 6.5 & 10.5 & 7.0 & 21 & 9.4 \\
\hline $\mathrm{D} \delta_{2}-\mathrm{D} \delta_{3}$ & 3.8 & 9.2 & 5.8 & 11.0 & 6.7 \\
\hline $\mathrm{D} \delta_{2}-\mathrm{J} \delta_{1}$ & 2.8 & 8.2 & 4.8 & 10.0 & 5.7 \\
\hline
\end{tabular}

Appendix 3. Oligomers used in the PCR and / or direct sequencing analysis of TcR- $\delta$ and $\operatorname{IgH}$ genes rearrangements

\begin{tabular}{|c|c|c|}
\hline The name of code & PCR / Sequence & Sequence \\
\hline \multicolumn{3}{|l|}{ TcR- $\delta$ genes } \\
\hline \multirow{3}{*}{ V $\delta 1-5$ ' backward } & & $X b a \mathbf{I}$ \\
\hline & PCK & GAAGATCTAGACTCAAGCCCAGTCATCAGTATCC \\
\hline & & Sal I \\
\hline \multirow[t]{2}{*}{ V81-3' backward } & PCR/Seq & CGCGTCGACGCCTTAACCATTTCAGCCTTAC \\
\hline & & Sal I \\
\hline V82-5' backward & PCR & CGCGTCGACCAAACAGTGCCTGTGTCAATAGG \\
\hline V82-3' backward & Seq & $\begin{array}{l}\text { CGCGTCGACCTGGCTGTACTTAAGATACTTGC } \\
\text { Sal I }\end{array}$ \\
\hline D83-3' forward & PCR/Seq* & $\underset{B g l \mathrm{II}}{\text { GTAGATCTAGAAATGGCACTTTTGCCCCTGCAG }}$ \\
\hline $\mathrm{J} \delta 1-3^{\prime}$ forward & PCR & $\underset{B g l \text { II }}{\text { GAAGATCTAGACCTCTTCCCAGGAGTCCTCC }}$ \\
\hline \multicolumn{3}{|l|}{ IgH genes } \\
\hline FR3-5' backward & PCR/Seq & $\underset{\text { Eco RI }}{\text { ATGGAATTCACACGGC(CT)(GC)TGTATTACTGT }}$ \\
\hline LJH-3' forward & PCR/Seq* & CACCTGAGGAGACGGTGACC \\
\hline
\end{tabular}

5' and 3' extension of the nucleotide names indicates the location of the oligonucleotide primer within the gene segment. The restriction sites are indicated. Oligonucleotide primers used in PCR or sequence analysis are indicated PCR and sequence, respectively ${ }^{16}$.

* : The blotinylated primer was used for direct sequencing. 